\title{
Sistem Informasi Proses Produksi PT Tridaya Eramina Bahari
}

\author{
Salvian Iman Kumara' ${ }^{1)}$, Arie Kusumawati ${ }^{2)}$ \\ Sistem Informasi, Fakultas Industri Kreatif Institut Teknologi dan Bisnis Kalbis \\ Jalan Pulomas Selatan Kav. 22, Jakarta 13210 \\ Email:salvianiman@gmail.com \\ Email: arie.kusumawati@kalbis.ac.id
}

\begin{abstract}
PT. Tridaya Eramina Bahari is a company engaged in the exporter of marine fish processing. This company does not yet have an integrated system. The process is still manual, making the length of work process and frequent errors. The length of the process makes it difficult for a corporate leader to make a decision. This study aims to analyze and build information systems based on web production process using laravel framework. System development method used is prototype. System modeling uses UML (unified Model Language). Database design using ERD (Entity Relationship Diagram). Testing system using black box method with alpha testing type. The result of this research is production process information system used by company side to facilitate employee job.
\end{abstract}

Keywords: System, Information, Production, Web, Prototype, Uml

\begin{abstract}
Abstrak: PT. Tridaya Eramina Bahari merupakan perusahaan yang bergerak dibidang exporter pengolahan ikan laut. Perusahaan ini belum memiliki sistem yang terintegrasi. Proses yang dilakukan masih manual, membuat lamanya proses kerja dan sering terjadinya kesalahan. Lamanya proses tersebut membuat pemimpin perusahaan kesulitan untuk mengambil keputusan. Penelitian ini bertujuan untuk menganalisis dan membangun sistem informasi proses produksi berbasis web dengan menggunakan framework laravel. Metode pengembangan sistem yang digunakan adalah prototype. Pemodelan sistem menggunakan UML (unified Model Language). Perancangan basis data menggunakan ERD (Entity Relationship Diagram). Pengujian sistem menggunakan metode black box dengan jenis alpha testing. Hasil dari penelitian ini adalah sistem informasi proses produksi digunakan oleh pihak perusahaan untuk mempermudah pekerjaan karyawan.
\end{abstract}

Kata kunci: Informasi, Produksi, Prototype, Sistem, Web, Uml

\section{PENDAHULUAN}

PT. Tridaya Eramina Bahari adalah perusahaan yang bergerak di bidang eksportir ikan laut. Produk andalannya adalah ikan tuna, marlin, skip, todak, egois dan wahoo. Ikan tersebut ada yang berbentuk ikan utuh, tubuh ikannya saja (fillet), potong 4 bagian (split), kubus, steak dan berbagai macam pesanan sesuai permintaan pelanggan. Ikan tersebut diekspor ke berbagai Negara seperti Prancis, Portugal, Jerman, Belanda, Thailand, Vietnam dan Jepang. Kini perusahaan ini terus menambahkan kapasitas ekspornya agar bisa melayani semua pesanan dari para pelanggannya. Beberapa masalah yang terjadi di perusahaan ini diantaranya: Sistem yang digunakan masih masih manual dengan menggunakan Microsoft office dan penyimpanan data di setiap bagian serta masih menggunakan buku besar; Permasalahan proses kerja, karyawan bekerja tidak sesuai dengan pekerjaannya dan terlalu banyaknya Pekerjaan yang membuat tidak fokus dalam bekerja; Kurangnya koordinasi antara bagian sehingga sering terjadi kesalahan komunikasi yang dapat tidak terdistribusi informasi ke setiap bagiannya.

\section{METODOLOGI PENELITIAN}

Metodologi penelitian berisikan langkahlangkah peneliti dari awal sampai selesai. Gambar 1 menjelaskan gambaran metodologi penelitian penulis.

\section{A. Pengambilan Data Awal}

Pengambilan data awal peneliti melakukan dua tahapan yaitu:

1. Wawancara

Wawancara adalah bentuk komunikasi langsung antara peneliti dan responden melalui interaksi verbal/ lisan [1]. Peneliti melakukan wawancara 


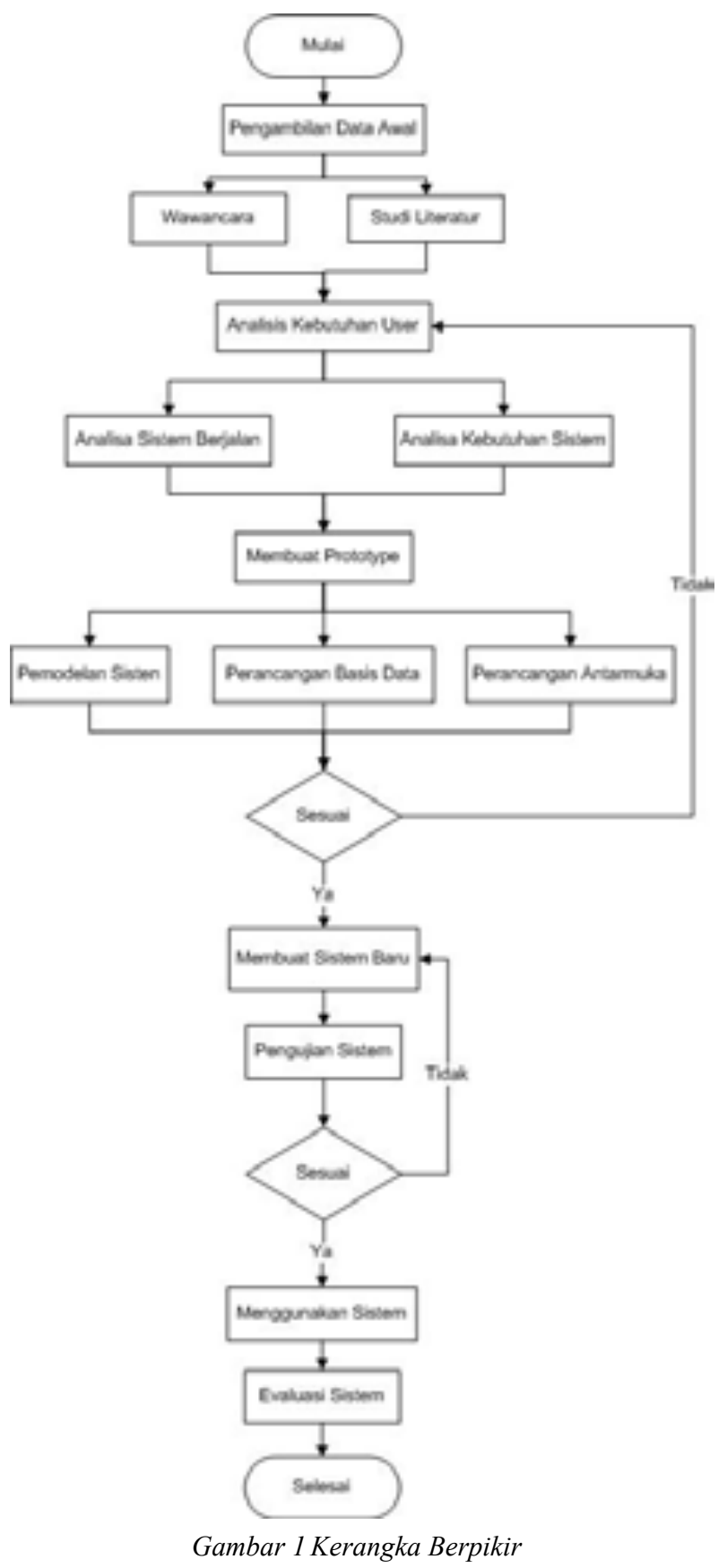

kepada pihak perusahaan mengenai proses berjalan, permasalahaan yang ada dan harapan perusahaan.

\section{Studi Literatur}

Studi literatur peneliti melakukan perbandingan dengan penelitian terdahulu dan mencari referensi yang terkait. peneliti menggunakan tiga penelitian terdahulu. Berikut tabel perbandingan peneliti dapat dilihat pada Tabel 1 .

Dari perbandingan tersebut dapat ditentukan peneliti menggunakan pengembanga sistem dengan metode prototyping. Prototyping merupakan teknik pengembangan sistem yang menggunakan prototype untuk menggambarkan sistem yang dibuat [5]. Prototype yang digunakan dengan jenis requirement prototype. Berikut gambar 2 adalah langkah-langkah dari requirement prototype.
Tabel 1Tabel Perbandingan Peneliti

\begin{tabular}{|c|c|c|c|c|}
\hline $\begin{array}{l}\text { pembandin } \\
\mathrm{g}\end{array}$ & 1 & 2 & 3 & Peneliti \\
\hline $\begin{array}{l}\text { Nama } \\
\text { Peneliti }\end{array}$ & $\begin{array}{l}\text { Cucu } \\
\text { Sapitri, } \\
\text { Tacbir } \\
\text { Hendro } \\
\text { Pudjianto } \\
\text { ro, Fajri } \\
\text { Rakhmat } \\
\text { Umbara } \\
\text { [2] }\end{array}$ & $\begin{array}{l}\text { Muhamma } \\
\text { d Iqbal } \\
\text { Hadi [3] }\end{array}$ & $\begin{array}{l}\text { Mohd Azmi } \\
\text { Hussin, } \\
\text { Shahrani } \\
\text { Shahbudin, } \\
\text { Nooritawati } \\
\text { Md Tahir } \\
\text { [4] }\end{array}$ & $\begin{array}{l}\text { Salvian } \\
\text { Iman } \\
\text { Kumara }\end{array}$ \\
\hline Judul & $\begin{array}{l}\text { Sistem } \\
\text { Informasi } \\
\text { Produksi } \\
\text { dan } \\
\text { pengenda } \\
\text { lian } \\
\text { Bahan } \\
\text { Baku } \\
\text { Pada CV } \\
\text { Bundar } \\
\text { Citra } \\
\text { Mandiri } \\
\end{array}$ & $\begin{array}{l}\text { Pengemba } \\
\text { ngan } \\
\text { Sistem } \\
\text { Informasi } \\
\text { Manufaktu } \\
\text { r Celana } \\
\text { Jeans }\end{array}$ & $\begin{array}{l}\text { Pengembang } \\
\text { an Sistem } \\
\text { Berbasis } \\
\text { Androids } \\
\text { untuk } \\
\text { Operasi } \\
\text { Manufaktur }\end{array}$ & $\begin{array}{l}\text { Sistem } \\
\text { Informa } \\
\text { si Proses } \\
\text { Produksi } \\
\text { PT. } \\
\text { Tridaya } \\
\text { Eramina } \\
\text { Bahari }\end{array}$ \\
\hline $\begin{array}{l}\text { Aplikasi } \\
\text { Berbasis }\end{array}$ & Web & Web & Android & Web \\
\hline $\begin{array}{l}\text { Metode } \\
\text { Pengemba } \\
\text { ngan } \\
\text { Sistem }\end{array}$ & $\begin{array}{l}\text { Prototypi } \\
\text { ng }\end{array}$ & Waterfall & Agile & $\begin{array}{l}\text { Prototyp } \\
\text { ing }\end{array}$ \\
\hline $\begin{array}{l}\text { Bahasa } \\
\text { Pemrogra } \\
\text { man }\end{array}$ & $\begin{array}{l}\text { PHP } \\
\text { dengan } \\
\text { Framewo } \\
\text { rk } \\
\text { codeigniit } \\
\text { er }\end{array}$ & PHP & Java & PHP \\
\hline Database & Mysql & Mysql & Cloud & Mysql \\
\hline $\begin{array}{l}\text { Hasil dan } \\
\text { Pembahasa } \\
\mathrm{n}\end{array}$ & $\begin{array}{l}\text { 1. Login } \\
\text { 2. Menu } \\
\text { Bahan } \\
\text { Baku } \\
\text { 3. Menu } \\
\text { Penerim } \\
\text { aan } \\
\text { Bahan } \\
\text { Baku } \\
\text { 4. Menu } \\
\text { Permint } \\
\text { aan } \\
\text { bahan } \\
\text { baku } \\
\text { 5. Menu } \\
\text { Pelapor } \\
\text { an } \\
\text { Grafik } \\
\text { Produks } \\
\text { i }\end{array}$ & $\begin{array}{l}\text { 1. Login } \\
\text { 2. Menu } \\
\text { Inventori } \\
\text { 3. Menu } \\
\text { Pemolaa } \\
\mathrm{n} \\
\text { 4. Menu } \\
\text { Penjahita } \\
\mathrm{n} \\
\text { 5. Menu } \\
\text { Laundry } \\
\text { 6. Menu } \\
\text { Finishing } \\
\text { 7. Menu } \\
\text { Manager }\end{array}$ & $\begin{aligned} & \text { 1. } \text { Login \& } \\
& \text { Registrasi } \\
& \text { 2. } \text { Menu } \\
& \text { staff } \\
& \text { Directory } \\
& \text { 3. } \text { Menu } \\
& \text { calender } \\
& \text { 4. } \text { Menu JF } \\
& \text { sistem } \\
& \text { informasi } \text { ing } \\
& \text { 5. } \text { Report } \\
& \text { 6. } \text { Comunic } \\
& \text { ation hub }\end{aligned}$ & - \\
\hline
\end{tabular}

\section{B. Analisa Kebutuhan User}

Analisa kebutuhan user peneliti melakukan dua analisa yaitu :

\section{Analisa Sistem Berjalan}

Peneliti menggambarkan proses bisnis yang sedang berjalan dengan menggunakan flowchart. Flowchart atau bagan alur merupakan metode untuk menggambarkan tahapan penyelesaian masalah (prosedur) beserta aliran data dengan simbol-simbol standar yang mudah dipahami [6]. 


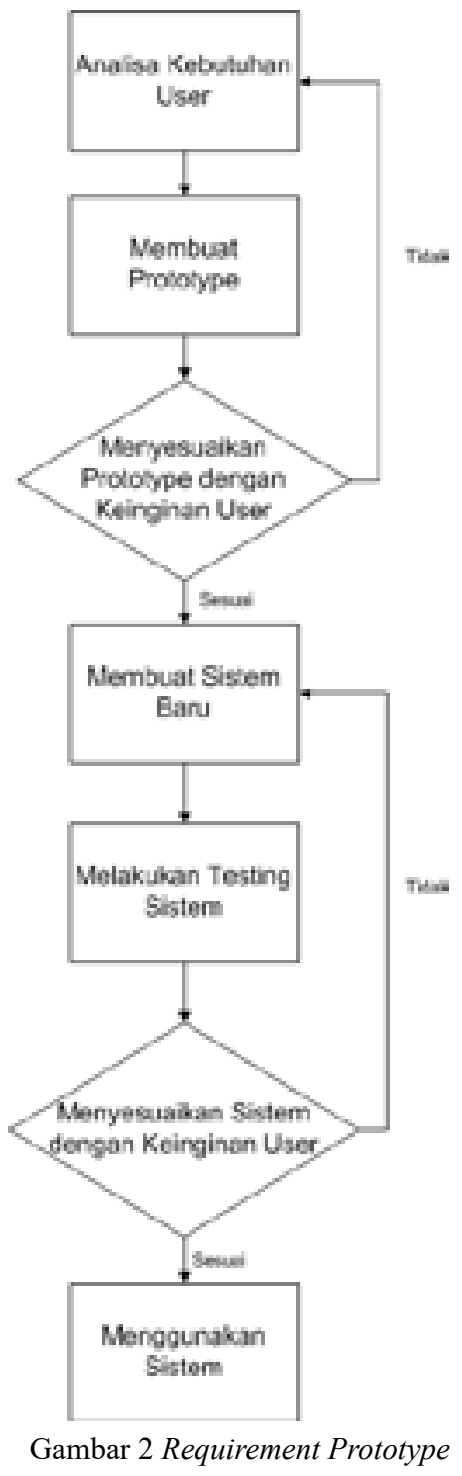

\section{Analisa Kebutuhan Sistem}

Peneliti melakukan analisa kebutuhan sistem dengan membuat kebutuhan fungsional dan kebutuhan non fungsional. Dalam analisa ini peneliti melakukan pengumpulan data-data yang terkait fungsi yang dibutuhkan didalam sistem dan memilih software dan database yang akan digunakan.

\section{Membuat Prototype}

Membuat prototype peneliti melakukan tiga perancangan yaitu :

1. Pemodelan Sistem. Dalam membuat pemodelan sistem, peneliti menggunakan UML dengan empat macam diagram yaitu activity diagram, use case diagram, sequence diagram, dan class diagram. UML merupakan bahasa pemrograman visual untuk pemodelan dan komunikasi mengenai sebuah sistem dengan menggunakan diagram dan teks-teks pendukung [7]

2. Perancangan Basis Data. Dalam perancangan basis data, peneliti menggunakan ERD (Entity Relationship Diagram) dengan dua pengembangan yaitu CDM dan PDM. ERD adalah bentuk paling awal dalam melakukan perancangan basis data relasional.

3. Perancangan Antarmuka. Perancangan antarmuka dibuat untuk menggambarkan sistem yang akan dibuat. Peneliti membuat rancangan antarmuka sesuai dengan yang dibutuhkan oleh pengguna.

\section{Membuat Sistem Baru}

Peneliti melakukan pembuatan sistem apabila prototype yang dibuat telah sesuai dengan kebutuhan pengguna. Sistem yang dibuat menggunakan PHP atau disebut Hypertext Preprocessor adalah Bahasa scripting open source yang digunakan untuk pengembangan web dan dimasukan kedalam HTML [8]. Framework yang digunakan yaitu Laravel. Laravel adalah kerangka kerja aplikasi web dengan sintaks yang lebih ekspresif dan elegan [9]. database yang digunakan menggunakan MySQL. Mysql adalah database open source yang terkenal di dunia dengan kinerja, keandalan dan kemudahan penggunaannya [10].

\section{E. Pengujian Sistem}

Peneliti menggunakan pengujian alfa dengan melibatkan pengguna akhir untuk mengetahui apakah fungsi dari sistem telah berjalan dengan baik dan tidak ada kesalahan [11]. Pada jenis pengujian ini pengguna akan diundang ke pusat pengembangan. Pengguna akan melakukan pengujian langsung terhadap aplikasi yang dibuat dan pengembang akan mencatat setiap masukan atau tindakan yang dilakukan oleh pengguna. Semua jenis perilaku yang tidak normal dan sistem dicatat dan dikoreksi oleh para pengembang. Semua jenis prilaku sistem yang tidak normal dari sistem, dicatat dan dikoreksi oleh peneliti. Apabila sistem ada masalah dan tidak sesuai dengan keinginan user maka sistem akan di perbaiki.

\section{F. Menggunakan Sistem}

Sistem yang telah selesai dibuat dan sudah dilakukan pengujian sistem maka sistem tersebut dapat digunakan oleh pihak perusahaan.

\section{G. Evaluasi Sistem}

Peneliti melakukan pengamatan terhadap sistem yang telah di implementasikan dan menarik kesimpulan terhadap sistem.

\section{PHASIL DAN EMBAHASAN}

Pembahasan peneliti akan membahas tentang sistem yang berjalan, perancangan, pengujian dan hasil sistem yang dibuat. 


\section{A. Analisa Kebutuhan User}

Peneliti melakuakan dua analisa yaitu analisa sistem berjalan dan analisa kebutuhan sistem: (1) Proses Bisnis Berjalan. Proses bisnis berjalan adalah proses sistem kerja yang sedang berjalan pada PT Tridaya Eramina Bahari. Proses bisnis berjalan digambarkan dengan menggunakan flowchart; dan (2) Analisa Kebutuhan Sistem. Peneliti melakukan dua analisa yaitu analisa kebutuhan fungsional dan kebutuhan non fungsional.

Kebutuhan fungsional merupakan kebutuhan yang berisi fungsi-fungsi yang dilakukan oleh sistem. Sistem informasi proses produksi pada PT Tridaya Eramina Bahari digunakan oleh beberapa bagian diperusahaan. Bagian yang menggunakan sistem yaitu bagian marketing, pembelian, produksi, gudang, keuangan, admin dan pemimpin perusahaan. Fungsi dari setiap bagian ditampilkan dalam menumenu pada aplikasi yang dirancang beserta fitur-fitur pada setiap fungsinya. Berikut Tabel 2 merupakan kebutuhan fungsional.

Kebutuhan non fungsional adalah kebutuhan yang berkaitan langsung dengan komponen yang digunakan dalam pembuatan sistem. Tabel 3 menggambarkan kebutuhan non fungsional pada perusahaan.

\section{B. Perancangan Sistem}

Perancangan sistem yang akan dibuat dengan menggunakan UML. UML yang digunakan ada empat yaitu class diagram, activity diagram, use case diagram dan sequence diagram.

\section{Use Case Diagram.}

Peneliti melakukan wawancara kepada pengguna mengenai kebutuhan yang diperlukan pada sistem informasi yang akan digunakan. Sistem yang digunakan seperti fungsi-fungsi yang terdapat pada sistem, tujuan dari fungsi-fungsi yang disediakan yaitu aktor atau user yang dapat menggunakan sistem dan berinteraksi degan fungsi tersebut. Dari wawancara tersebut peneliti menggambarkannya menjadi use case diagram. Use case diagram merupakan pemodelan untuk kelakukan (behaviour) sistem informasi yang akan dibuat [12].

\section{Activity Diagram.}

Activity diagram atau bisa disebut diagram aktivitas, menggambarkan aliran kerja (workflow) atau aktivitas dari sebuah sistem atau proses bisnis atau menu yang ada pada perangkat lunak [13]. Aktivitas diagram akan menggambarkan menu dalam sistem yang dilakukan oleh setiap aktor. Aktor yang
Tabel 2 Kebutuhan Fungsional

\begin{tabular}{|c|c|c|c|}
\hline No & Aktor & Fungsi & Fitur \\
\hline$\overline{1} 1$ & Marketing & $\begin{array}{l}\text { 1. Login } \\
\text { 2. Data } \\
\text { pemesanan } \\
\text { produk } \\
\text { 3. Data Pembeli }\end{array}$ & $\begin{array}{l}\text { Untuk masuk kedalam sistem } \\
\text { 1. Menampilkan, mengubah } \\
\text { dan menghapus pesanan } \\
\text { 2. Melihat data pesanan } \\
\text { 1. Memasukan, mengubah } \\
\text { dan menghapus pembeli } \\
\text { 2. Melihat data pembeli }\end{array}$ \\
\hline 2 & Produksi & $\begin{array}{ll}\text { 1. } & \text { Login } \\
\text { 2. } & \text { Data Proses } \\
& \text { Produksi }\end{array}$ & $\begin{array}{l}\text { Untuk masuk kedalam sistem } \\
\text { 1. Merubah status produksi } \\
\text { 2. Permintaan bahan } \\
\text { produksi } \\
\text { 3. Menambahkan jumlah } \\
\text { produksi selesai }\end{array}$ \\
\hline 3 & Gudang & $\begin{array}{l}\text { Data } \\
\text { Kebutuhan } \\
\text { Produksi }\end{array}$ & $\begin{array}{l}\text { Untuk masuk kedalam sistem } \\
\text { 1. Melihat stok } \\
\text { 2. Memasukan stok baru } \\
\text { 3. Melihat data stok masuk } \\
\text { 4. Menghapus data stok } \\
\text { masuk } \\
\text { Menyetujui permintaan } \\
\text { bahan produksi }\end{array}$ \\
\hline 4 & Direktur & $\begin{array}{ll}\text { 1. } & \text { Login } \\
\text { 2. } & \text { Data proses } \\
\text { produksi } \\
\text { 3. } & \text { Data Stok }\end{array}$ & $\begin{array}{l}\text { Untuk masuk kedalam sistem } \\
\text { Melihat proses produksi } \\
\text { Melihat stok bahan baku }\end{array}$ \\
\hline 5 & Admin & $\begin{array}{ll}\text { 1. } & \text { Login } \\
\text { 2. } & \text { Data } \\
& \text { Pegawai } \\
\text { 3. } & \text { Data ikan }\end{array}$ & $\begin{array}{l}\text { Untuk masuk kedalam sistem } \\
\text { 1. Memasukan, mengubah dan } \\
\text { menghapus data pegawai } \\
\text { 2. Melihat data pegawai } \\
\text { 1. Memasukan ikan } \\
\text { 2. Mengubah ikan } \\
\text { 3. Menghapus data data ikan } \\
\text { 4. Melihat data ikan } \\
\text { 1. Memasukan data proses } \\
\text { pengolahan ikan } \\
\text { 2. mengubah data proses } \\
\text { pengolahan ikan } \\
\text { 3. menghapus data proses } \\
\text { pengolahan ikan } \\
\text { 4. Melihat data proses } \\
\text { pengolahan ikan }\end{array}$ \\
\hline
\end{tabular}

berperan dalam penggunaan sistem yaitu bagian marketing, bagian pembelian, bagian produksi, bagian keuangan, bagian gudang, admin dan direktur perusahaan.

3. Sequence diagram.

Diagram sekuen menjelaskan hubungan antara objek dengan basis data. Diagram sekuen menggambarkan kelakuan objek pada use case dengan mendeskripsikan waktu hidup objek dan massage yang dapat dikirimkan dan diterima antar objek [14].

4. Class Diagram.

Peneliti melakukan perancangan class diagram untuk aplikasi yang dibuat sesuai dengan kelas yang sudah digambarkan di class diagram. Class diagram atau disebut juga diagram kelas menggambarkan struktur sistem dari segi pendefinisian kelas-kelas yang akan dibuat untuk membangun sistem [15]. Kelas kelas yang ada pada struktur sistem harus sesuai dengan kebutuhan sistem, sehingga pada saat pembuatan sesuai dengan gambarannya. 
Tabel 3 Kebutuhan Non Fugsioal

\begin{tabular}{|c|c|c|}
\hline No & Komponen & Deskripsi \\
\hline 1. & $\begin{array}{l}\text { Perangkat } \\
\text { keras }\end{array}$ & $\begin{array}{l}\text { Windows } 8 \text { dengan minimum } \\
\text { spesifikasi perangkat keras : } \\
\text { 1. Sistem Operasi 64-bit } \\
\text { 2. Ram sebesar } 4 \text { GB } \\
\text { 3. VGA } \\
\text { 1. Alat masukan (keyboard \& } \\
\text { Mouse) } \\
\text { 2. Alat Pemroses (CPU, } \\
\text { RAM, VGA Card) } \\
\text { 3. Alat penyimpanan Data } \\
\text { (Harddisk) } \\
\text { 4. Alat Keluaran (Monitor) }\end{array}$ \\
\hline 2. & $\begin{array}{l}\text { Perangkat } \\
\text { Lunak }\end{array}$ & $\begin{array}{l}\text { 1. Sistem Operasi Widows } 8 \\
\text { 2. Notepad++ versi } 7.5 .4 \\
\text { 3. Xampp for windows versi } \\
\text { 7.2.2 } \\
\text { 4. Google Crome } \\
\text { 5. Laravel 5.1 }\end{array}$ \\
\hline
\end{tabular}

\section{Perancangan Basis Data}

Peneliti akan menggambarkan perancangan basis data yang akan dibuat dengang menggunakan ERD. ERD yang digunakan ada dua yaitu conceptual data model (CDM) dan physical data model (PDM).

\section{Conceptual Data Model (CDM)}

Conceptual Data Model (CDM) atau model konsep data adalah konsep yang berkaitan dengan pandangan pemakai terhadap data yang disimpan dalam basis data [16]. CDM menjabarkan konsep yang berkaitan dengan pandangan pemakai terhadap data yang disimpan dalam basis data. CDM dibuat sudah dalam bentuk tabel-tabel tanpa tipe data yang menggambarkan relasi antar tabel untuk keperluan implementasi ke basis data.

\section{Physical Data Model (PDM)}

Physical Data Model (PDM) atau disebut dengan model relasional adalah model yang menggunakan sejumlah tabel untuk menggambarkan data serta hubungan antar data [17]. PDM (Physical Data Model) menjelaskan model yang menggunakan sejumlah tabel untuk menggambarkan data serta hubungan antara data. Dimana setiap tabel mempunyai sejumlah kolom dimana setiap kolom memiliki nama yang unik beserta tipe datanya.

\section{Perancangan Antar Muka}

Perancangan antar muka digunakan untuk menggambarkan tampilan rancangan sistem.

(1) Rancangan Halaman Masuk. Rancangan halaman masuk merupakan tampilan awal sistem. Sebelum masuk ke sistem maka akan menampilkan halaman login terlebih dahulu; (2). Rancangan Halaman Awal Masuk. Rancangan halaman awal masuk merupakan halaman pertama kali pengguna masuk kedalam sistem. Setelah pengguna memasukan nama pengguna dan kata sandi akan menampilkan halaman ini; (3) Rancangan Halaman Data Pembeli. Rancangan halaman data pembeli berisikan data pembeli. Data pembeli ini digunakan untuk melakukan pemesanan ikan; (4) Rancangan Halaman Pemesanan. Rancangan halaman pemesanan digunakan untuk memasukan pemesanan dari pembeli. Pemesananan ini sesuai dengan data pembeli yang ada; (5) Rancangan Halaman Detail Pemesanan. ancangan halaman detail pemesanan digunakan memasukan pemesanannya. Detail pemesanan ini berisikan banyaknya pemesanan dari satu pembeli (6) Rancangan Halaman Data Pegawai. Rancangan halaman data pegawai berisikan data pegawai di perusahaan. Data pegawai ini digunakan untuk pegawai yang menggunakan sistem; (7). Rancangan Halaman Proses Produksi. Rancangan halaman proses produksi digunakan untuk menampilkan pesanan yang ada dan untuk memproduksi sesuai pesanan; (8) Rancangan Halaman Detail Proses Produksi. Rancangan halaman detail proses produksi manmpilkan data detail pemesanan dan pemesanan itu akan di proses sesuai dengan pesanan yang ada; (9) Rancangan Halaman Mengelola Kebutuhan Produksi. Rancangan halaman mengelola kebutuhan produksi berisikan permintaan bagian produksi atas bahan baku atau ikan; (10) Rancangan Halaman Data Stok Ikan. Rancangan halaman data stok ikan berisikan stok ikan yang ada di gudang; (11) Rancangan Halaman Proses Pengolahan Ikan. Rancangan halaman data proses pengolahan ikan berisikan data proses pengolahan ikan. Data ini digunakan untuk proses apa saja yang bisa dilakukan bagian produksi; dan (12) Rancangan Halaman Data Ikan. Rancangan halaman data ikan berisikan ikan data ikan yang pernah di pesan oleh semua pembeli.

\section{E. Pengujian Sistem}

Dalam melakukan pengujian sistem, peneliti melakukan pengujian sistem dengan menggunakan pengujian alfa. Berikut contoh beberapa pengujian sistem pada tampilan login, tampilan halaman marketing dan tampilan halaman produksi.

\section{Tampilan Halaman Login}

Pada tampilan login, pengguna dapatmemasukan nama pengguna dan kata sandi yang sudah terdaftar pada sistem. Pengguna sistem ini dibagi menjadi beberapa bagian yaitu admin, direktur, marketing, 
produksi dan gudang. Ketika pengguna memasukan nama pengguna dan kata sandi yang sesuai maka sistem akan masuk ke halaman utama sesuai dengan bagian pekerjaannya.

Jika nama pengguna atau kata sandi salah, maka sistem tidak akan masuk ke halaman utama. Sistem akan menampilkan informasi kesalahan masukan nama pengguna dan kata sandi.

\section{Tampian Halaman Marketing}

Halaman marketing dapat dilihat pada Gambar 3. marketing dapat mengelola data pembeli dan data pemesanan. Mengelola data pembeli marketing dapat menambahkan data pembeli, mengubah data pembeli dan menghapus data pembeli. Mengelola data pemesanan marketing dapat menambahkan data pesanan mengubah dan menghapus pesanan.

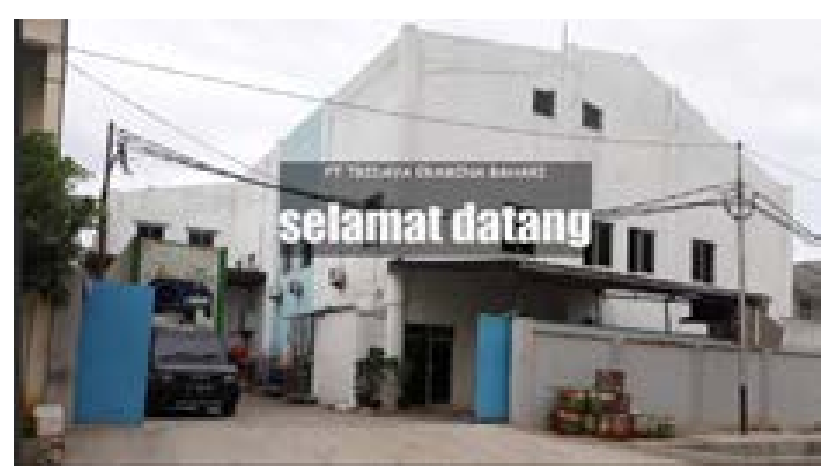

Gambar 3 Halaman Awal Marketing

Mengelola data pembeli, bagian marketing dapat menambahkan data, mengubah data, menghapus data dan tambah pesanan. Tombol tambah pesanan akan pindah halam dan menampilkan halaman pesanan sesuai dengan data pembeli. Data pembeli digunakan untuk memasukan data pemesan. Sebelum bagian marketing akan memasukan data pesanan, maka di cek terlebih dahulu data pembelinya. Apabila pembeli baru maka harus menambahkan data pembeli. Jika pembeli lama atau sudah ada datanya di sistem, maka dapat melakukan pemesanan dengan cara menekan tombol tambah pesanan. Proses tambah pesanan akan berpindah ke halaman pesanan.

Mengelola data pemesanan, bagian marketing dapat menambahkan pemesanan, mengubah pemesanan, menghapus pemesanan dan detail pesanan. Menambahkan data pesanan harus melalui data pembeli dan dipilih dari data pembeli tersebut dimana data pembeli yang ingin melakukan pemesanan. Ketika data pembeli sudah di pilih maka data nama perusahaan otomatis menampilkan nama perusahaan yang melakukan pemesanan. Masukan data pemesanan berisikan tanggal mulai dan tenggat waktu sesuai dengan data permintaan pembeli. Data sudah berhasil disimpan ketika menekan tombol tambah pesanan. Data akan tampil di data pesanan yang berada di bawah form menambahkan pesanan. Jika ingin ke detail pesanan maka tombol detail pesanan akan pindah halam dan menampilkan halaman detail pesanan sesuai dengan pemesanan.

Mengelola data detail pemesanan, bagian marketing dapat menambahkan detail pemesanan, mengubah detail pemesanan dan menghapus detail pemesanan. Data detail pesanan ini terhubung ke data pemesanan. ketika diisi datanya dan akan keluar penambahan detail pesanan. Detail pesanan juga bisa mengubah data. Pada saat mengubah data, data yang sudah masuk ke sistem akan di tampilkan di form untuk dapat merubah data tersebut dan menyimpan data kembali. data detail pesanan dapat menghapus data kembali.

\section{Tampilan Halaman Produksi}

Tampilan detail pesanan di bagian produksi akan menampilkan data pemesanan dan ditambah kolom jumlah selesai produksi. Bagian produksi dapat memilih tombol permintaan bahan produksi dan produksi. Bagian produksi akan melihat pesanan dan meminta bahan produksi untuk melakukan proses produksi. Permintaan bahan produksi akan menentukan jenis ikannya, melihat stok dan pemintaan bahan produksi. Permintaan bahan produksi tidak boleh melebihi jumlah stok. Jika bagian produksi meminta bahan produksi melebihi jumlah stok maka sistem akan memberi pesan bahwa pemesanan melebihi stok. Ketika bagian produksi salah melakukan penginputan data permintaan maka yang bisa menghapus permintaan adalah admin. Setelah stok dimasukan sesuia dengan proses produksi maka barang akan dikirim oleh bagian produksi.

Bagian produksi akan memasukan kolom jumlah selesai produksi ketika selesai melakukan produksi. Jumlah selesai produksi tidak bisa mengisi data melebihi pesanan. Jika bagian produksi memasukan memasukan proses produksi melebihi pemesanan maka akan ada pesan bahwa jumlah selesai tidak boleh melebihi pesanan. Ketika bagian produksi memasukan data jumlah selesai salah maka yang bisa memperbaiki adalah admin. Setelah bagian produksi menyelesaikan produksinya maka bagian produksi tekan tombol kembali untuk ke halaman pesanan produksi. Bagian gudang akan merubah status proses menjadi selesai.

\section{F. Menggunakan Sistem}

Peneliti merencanakan mengimplementasikan sistem secara langsung dengan melakukan hosting setelah dilakukan alpha testing. Tahapan 
implementasi yang dilakukan peneliti adalah: (1) Direncanakan membeli hosting dan domain dengan nama www.tridayaeraminabahari.com; (2) Memindahkan dokumen yang berisi pengkodean sistem kedalam hosting; (3) Membuat database baru dan mengeksport isi database lama ke database baru; dan (4) Memasukan data-data PT Tridaya Eramina Bahari ke dalam sistem informasi penjualan.

\section{G. Evaluasi Sistem}

Secara keseluruhan sistem informasi proses produksi PT Tridaya Eramina Bahari dengan lancar. Hasil dari pengujan sistem kepada pihak perusahaan sesuai dengan keinginan. Pihak perusahaan menginginkan menggunakan sistem tersebut. Direncanakan sistem menggunakan hosting untuk dipergunakan oleh pihak perusahaan. Evaluasi sistem akan dilakukan ketika sistem sudah digunakan oleh perusahaan.

\section{SIMPULAN}

Pada penelitian ini dihasilkan Sistem Informasi Proses Produksi PT Tridaya Eramina Bahari berbasis website yang dapat menghubungkan pemesanan, proses produksi dan stok bahan baku. Sistem ini menghubungkan bagian marketing, produksi, gudang, direktur dan admin. Sistem ini membantu karyawan dalam mengelola pesanan, mengelola pembeli, mengelola produksi, mengelola kebutuhan produksi, mengelola stok bahan baku, mengelola permintaan kebutuhan produksi, mengelola pegawai, mengelola data ikan dan mengelola data proses pengolahan ikan. Dengan sistem ini karyawan dapat memudahkan pekerjaan, karena sistem yang digunakan sudah terintegrasi dengan beberapa bagian.

\section{DAFTAR RUJUKAN}

[1] M. Suwartono, "Wawancara," in Dasar-Dasar Metodologi Penelitian, Yogyakarta, Andi, 2014, pp. 48-51.

[2] C. Sapitri, H. Pudjiantoro and F. R. Umbara, "Sistem Informasi Produksi dan Pengendalian Bahan Baku Pada CV Bundar Citra Mandiri,” in Prosiding Seminar Nasional Komputer dan Informatika, Cimahi, 2017.

[3] M. I. Hadi, "Repositori UIN Syarif Hidayatullah Jakarta,” 2011. [Online]. Available: http://repository. uinjkt.ac.id/dspace/bitstream/123456789/5041/1/ MUHAMMAD\%20IQBAL\%20HADI-FST.pdf. [Accessed 23 Januari 2018].
[4] M. A. Hussin, S. Shahbudin and N. M. Tahir, "Development of Androids Based System for Manufacturing Operation," IEEE Conference on Systems, pp. 230-235, 2016.

[5] S. Mulyani, "Metode Pengembangan Sistem (system Development Life Cyecle/SDLC)," in Metode Analisis dan Perancangan Sistem, Bandung, Abdi Sistematika, 2016, pp. 26-30.

[6] B. Soeherman and M. Pinontoan, "flowchart," in Designing Information System, jakarta, PT Elex Media Komputindo, 2008, pp. 133-137.

[7] R. A. Sukamto and M. Salahudin, "Pengenalan UML," in Rekayasa Perangkat Lunak Tertruktur dan Berorientasi Objek, Bandung, Informatika, 2015, pp. 137-140.

[8] PHP, “what is PHP?," PHP, [Online]. Available: http:// php.net/manual/en/intro-whatis.php. [Accessed 6 Maret 2018].

[9] Laravel, "Introduction," Laravel, [Online]. Available: https://aravel.com/docs/4.2/introduction. [Accessed 6 Maret 2018].

[10] Mysql, “about,” Mysql, [Online]. Available: https:// www.mysql.com/about/. [Accessed 6 Maret 2016].

[11] J. Simarmata, "Pengujian Alfa," in Rekayasa Perangkat Lunak, Yogyakarta, Andi, 2010, p. 321.

[12] R. A. Sukamto and M. Salahudin, "Use Case Diagram," in Rekayasa Perangkat Lunak Tertruktur dan Berorientasi Objek, Bandung, Informatika, 2015, pp. 156-157.

[13] R. A. Sukamto and M. Salahudin, "Activity Diagram," in Rekayasa Perangkat Lunak Tertruktur dan Berorientasi Objek, Bandung, Informatika, 2015, pp. 161-163.

[14] R. A. Sukamto and M. Salahudin, "Squence Diagram," in Rekayasa Perangkat Lunak Tertruktur dan Berorientasi Objek, Bandung, Informatika, 2015, pp. 165-166.

[15] R. A. Sukamto and M. Salahudin, "Class Diagram," in Rekayasa Perangkat Lunak Tertruktur dan Berorientasi Objek, Bandung, Informatika, 2015, pp. 141-147.

[16] R. A. Sukamto and M. Salahudin, "CDM," in Rekayasa Perangkat Lunak Tertruktur dan Berorientasi Objek, Bandung, Informatika, 2015, pp. 59-63.

[17] R. A. Sukamto and M. Salahudin, "PDM," in Rekayasa Perangkat Lunak Tertruktur dan Berorientasi Objek, Bandung, Informatika, 2015, pp. 63-64. 
Kalbiscentia, Jurnal Sains dan Teknologi, Volume 7, No. 2, Agustus 2020 